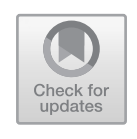

\title{
Towards an Analytical Framework to Study Annulments in the EU
}

Annulment actions are a legal weapon in the political fight between actors. The aim of engaging in annulment litigation is to shape the making of public policies and to influence the distribution of competences or the flow of funds. To explore the politics of annulments, our starting point is the proposition that courts can only speak in reaction to litigation initiated by actors enmeshed in complex policy conflicts. In that perspective, the Court of Justice of the European Union (CJEU) and its rulings are just a result of conflicts deliberatively escalated to the judicial arena in the struggle between opposing actors to trigger favourable decisions that serve their regulative and redistributive interests. Annulment actions can thus be conceived as tools employed by stakeholders fighting to defend their interests in a multilevel policy context. With this analytical vantage point come several questions. Most importantly, we must answer the question of how to conceptualize annulment conflicts and their underlying struggles. What are the relevant analytical questions to raise? In this chapter, we seek orientation from existing scholarly works in order to develop an analytical framework allowing us to engage in the empirical analysis of annulment actions and the respective motivations of actors.

In the following, we engage with three specific strands of literature that potentially enrich and orient our understanding of annulment litigation. They do so from different angles and thus contribute to different aspects of our research. First, scholars interested in multilevel governance

(C) The Author(s) 2020

C. Adam et al., Taking the EU to Court, Palgrave Studies in European Union Politics, https://doi.org/10.1007/978-3-030-21629-0_2 
and evolution of the European Union's (EU's) political system inform our understanding of how conflict emerges in the EU. Second, public policy analysis forms our view on implementation and the role of judicial proceedings in EU policy making. Moreover, third, judicial politics underline that actors strategically shape legal conflicts. Based on communalities and differences with the arguments presented in these strands of literature, we develop three specific research questions, which will further guide our empirical analysis of EU annulment conflicts in the remainder of this book. In a nutshell, we argue that analyses of annulment litigation need to focus on three aspects. First, we need to analyse the motivations - particularly those of public actors - to understand why they raise such cases. Second, we need to assess the actor configurations that characterize and influence judicial proceedings. Third, we must identify judicial outcomes (who loses and who wins?) along with their impact on policy substance and distribution of competence in the EU multilevel setting.

\section{Research Questions}

Essentially, we address three research questions. They are related to (1) the use of annulment actions, (2) their structure, and (3) their outcome and impact.

Our first question deals with the emergence of annulment actions: why do actors decide to litigate? The EU's multilevel policy process involves many distinct actors located at different governmental levels and active in different arenas. As a result, a wide array of interests, political preferences, values, cultures, and understandings interact and sometimes clash in the policy process. Conflicts between these actors have been widely studied in the context of policy making in the legislative arena. Sometimes, however, these policy conflicts are resolved within the judicial arena. Annulment actions constitute one legal channel for resolving some of these policy conflicts within the judicial arena. The question, however, is what motivates actors to turn to annulment actions to pursue their goals in the EU's multilevel policy context?

The second question deals with the structure of annulment actions. On a descriptive level, we ask about which actor configurations characterize annulment actions. The multilevel governance approach conceives EU governance as composed of a variety of interactions between a wide range of actors in the EU public policy process. What kind of actor 
configurations can we observe in annulment actions? Who litigates most and why? Are the conflict lines observable in the policy process reflected in litigation constellations? Which alliances and lines of cooperation are we likely to observe, and why? On a more analytical level, we therefore ask about determinants of different actor configurations and explore the impact of structure in this regard.

Third, we explore the outcome of annulment actions (i.e. rulings). How often are annulment actions successful, and why? Are some actors more likely to win than others? And are some actor configurations more successful than others? Most importantly, we explore the question of how certain we can be that any observed link between litigant configuration and judicial outcome results from a causal impact of that litigant configuration on the Court and not from unobserved factors that give rise to different litigant configurations and legal outcomes at the same time. In this regard, we also assess the impact of annulment actions on the multilevel policy context and on policy stakeholders and explore whether legal success in court is always aligned with political success or not. The discussion below will elaborate these different lines of inquiry.

\section{Multilevel Governance and Conflict in the EU}

Much of the literature on multilevel governance looks at the EU as a specific political system. It provides important insights on actors and shapes our thinking on how conflict emerges from their interactions in the European political arena. Since the early 1990s, the EU system has been increasingly characterized as multileveled. In contrast to classical political systems, the multilevel concept stresses vertical collaboration, the multiplicity of actors taking part in EU governance, and the loose coupling of levels and arenas (Marks 1993; Marks et al. 1996; Hooghe 1996; Benz and Eberlein 1999; Hooghe and Marks 2001; Tatham and Bauer 2014b). The multilevel governance perspective focuses-at least conceptually - on the opportunities emerging from interaction, coordination, and cooperation of governments and non-state actors on multiple levels, forming institutional linkages and politics beyond a clear hierarchy (Tatham and Bauer 2014a). Implicitly, in these interactions, conflicts about policy and the distribution of competences play a key role. They do so, for example, in the form of rivalry between subnational actors and national governments in their relationship with the EU (Hooghe and Marks 2001, 115). However, the conceptualization 
of the conflict surrounding multilevel governance arrangements has been afforded less room than the analysis of new forms of collaboration and engagement. On the rare occasions that policy conflict gets more attention, as in the cases with the joint decision trap (Scharpf 1985, 2006; Falkner 2011), multilevel conflict is conceived as a constraint for collective action. Conflict is typically associated with a form of blockage rather than as a dynamic process able to escalate diverging views to an eventual (court) decision. Thus, although conflict is implicit in this literature, it has not been a central concern for multilevel governance scholars. Consequently, it seems fair to stress the limitations of existing works on EU multilevel governance when it comes to the emergence of conflicts among actors of various political levels, the mediation of such conflict over policy decisions by the judiciary, and the potentially resulting new dynamics, feedback effects, and structuring elements for public policy. To be fair, Stone Sweet (1999) and Kelemen (2011) have laid some groundwork for analysing the role of legal conflict from a perspective of multilevel governance. In particular, Kelemen's argument about an emerging Eurolegalism stresses how features of the EU system link to litigation. Yet these works focus on the emergence of court rulings rather than their specific characteristics and outcomes.

It is not that multilevel conflict has been completely absent from pertinent scholarly conceptualizations. Empirical accounts found that the propensity for multilevel conflict has increased in the EU in recent decades (Bauer and Trondal 2015a, b). This rise has occurred for a number of reasons. With the intensification of EU integration in level and scope (Biesenbender 2011; Börzel 2005), there was just more to argue about. Since each treaty change increased the scope of issues the EU is able to legislate, the potential for disagreement about how to legislate, implement, and enforce legislative decisions automatically expands.

Besides, with the delegation of new powers to the supranational level, the boundaries of the competences and the precise procedures applying to the related decision-making processes often become-before accepted routines emerge-a matter of contest (see, for example, Farrell and Héritier 2007; Hartlapp 2018). Thus, the legal transfer and the practical wielding of new supranational powers do increase the potential for national resistance (Saurugger and Terpan 2013; Crespy and Saurugger 2014; Mathieu and Bauer 2018), as well as for conflicts between supranational and national authorities. Even in spite of an increasingly differentiated integration process (Holzinger and Schimmelfennig 2012), 
the trend towards vesting ever more competence at the supranational level remains unbroken; every revision of the founding treaties has conferred more powers to Brussels. Therefore, it does not come as a surprise that the potential for contesting the usage of these powers and the proper application of emerging rules become ever more likely (Bauer 2001).

If the range of issues to argue about has increased, so has the number and diversity of actors taking part in the policy process. At the institutional level, the days when the Commission and the Council were the sole relevant actors of EU policy making are long gone. With the increasing influence of the European Parliament (EP) (Corbett et al. 2011), the formal integration of the Council of the European Union (Naurin and Wallace 2008), political moves of the European Central Bank (Glöckler et al. 2016), and the boom of EU agencies, EU regulatory networks, and various types of committees (Dehousse 1997; Christiansen and Kirchner 2000; Egeberg 2006), the EU institutional landscape has become considerably more complex. First, each new actor comes with its own institutional interests, which may clash with those of the preexisting actors. Second, as these emerging actors are gradually empowered, their incentive and capacity to engage in conflictive relationship with the remaining actors increase as well (Bauer and Becker 2014). Enlargement has had a similar effect, as it increased the diversity of interests and political preferences (Meardi 2000; Kvist 2004) and generated distributional tensions between the member states (Pluemper and Schneider 2007). In short, with the growth of the EU and changes in its institutional setting, the propensity for tensions and conflicts among its components has increased (Ege et al. 2018). Indeed, the heterogeneity of identities, interests, and situations among actors pertaining to the same political system increases the likelihood of conflict (Blau 1977; Horowitz 1985). Yet the constitutional and therefore locked-in status of much of EU governance and the high number of veto players make it very difficult for each institution individually to influence the course of EU policies via the legislative channel. These rising constraints have been shown to foster informal politics (Christiansen and Neuhold 2013) and may well encourage the use of litigation as an alternative strategy to achieve political objectives (Swenden 2006, 79).

At the same time, the EU's policy process shifted from technocracy to a more contentious style of decision making. From the mid-1980s, with the turn from government to governance and with the broadening scope of issues covered by EU policies, a multitude of interest 
groups (financial institutions, industry, non-profit organizations, and regional and local governments) began to mobilize and intervene in the policy process, intensifying the political pressures on decision-taking elites (Mazey and Richardson 1993; McLaughlin and Greenwood 1995; Tömmel and Verdun 2008). Subnational governments have also entered the picture, with the establishment of representative offices in Brussels (Bauer 1996) and via their participation in regional policy making through the partnership principle (Bauer 2002). Far from fostering consensual decision making across governmental levels, this has fuelled political conflict and rivalry between central and subnational governments (Hooghe and Marks 2001, 115; Trondal and Bauer 2017).

In parallel, not only has the EU policy process been permeated by interest groups and subnational actors, it has also become increasingly vulnerable to pressures from public opinion (Hooghe and Marks 2009; Hix 2011). The popular opposition to the EU project expressed by citizens via referenda (Danish rejection of the Maastricht Treaty in 1992, French rejection of the Constitutional Treaty in 2005, and the recent British refusal to remain in the EU) has further made clear that public opinion matters. As they take part in the confrontation of interests that mark the EU political process, public opinion, interest groups, and subnational governments have significantly increased the potential for conflict in the EU.

Finally, in the last few years, the rise of tensions and crises on the global scene has intensified the potential for conflict within the EU. With the financial crisis and Great Recession, the explosion of armed conflicts in its southern and eastern neighbourhood, and the ascent of a new nationalism, the EU has been jumping from one crisis to another. Caught between gravity and urgency, the EU and the member states search for ways to manage and solve these crises. The results are often situations with high distributional stakes, which increases the propensity for conflict, as illustrated by the Greek crisis, the refugee crises, and the Brexit process. Solidarity crumbles with the growing divergence of interests between net donors and net recipients of EU spending policies (Scharpf 2017), between the Visegrad Group and the remaining member states about refugees, and between pro-European and Euro-scepticsto name just a few of the cleavages along which the EU currently risks being broken apart.

In sum, we see a changing nature of the EU political system and of policy making towards ever greater complexity and ever greater 
fragmentation. Competence and influence are shared and contested between many more actors at different levels than was traditionally the case. Kelemen (2011) argues that this has led to the substitution of consensus-oriented styles of policy making and embedding of policy struggles within networks with a more adversarial style of policy making and conflict. Such policy making-much like in the United Statesincreasingly relies on the threat and use of litigation. The strength of his argument is to link system features to litigation, therewith providing much support for an increasing relevance of litigation, including annulment actions. At the same time, the argument raises many new questions that engage more deeply with the link between system and litigation.

When do multilevel policy conflicts among the different actors populating the EU lead to litigation? What motivates policy actors to take the judicial step and turn to courts? Litigation may make sense for private actors that do not formally take part in the policy decisionmaking process. To them, activating judicial policy making through judicial review may appear as a promising mechanism. Litigation is more puzzling, however, when initiated by public actors who do take part in the EU decision-making process and most likely have done so in the very process from which the contested act or decision emerged. Yet annulment actions are regularly raised by member states, the Commission, the Council, and the EP. Why do these public actors litigate? What do they expect from a CJEU ruling? Which benefits do they draw from engaging in judicial proceedings? These are a first set of key questions that will structure our research.

Even more so, the multilevel structure of EU governance creates conflict that exhibits a multilevel structure as well. In fact, raising awareness of the fact that the EU's governance arrangement is characterized by multilevel actor configurations and thus requires interaction, cooperation, and coordination among different kinds of policy stakeholders and policymakers at different levels of government has been one of the main achievements of research on multilevel governance. When analysing annulment actions as one mechanism to resolve such multilevel conflicts, we should thus assess to what extent multilevel conflict configurations translate into multilevel litigant configurations during judicial proceedings.

After all, annulment proceedings do not always comprise only one applicant attacking only one defendant. While those simple configurations make up for the majority of cases, there are a significant 
number of judicial conflicts that exhibit a more complex structure, where several actors can simultaneously challenge one EU measure or where additional policy stakeholders decide to intervene in the conflict in support of the applicant or the defendant. Annulment conflicts are thus often complex, multi-actor, and multilevel. So far, however, we know rather little about the conditions under which multilevel governance systems give rise to simple and/or complex judicial conflicts.

\section{EU Policy Making and Litigant Configurations}

Research on EU policy making, the second literature strand relevant to our interest in annulment actions, provides insights into actors' motivations to engage with litigation. Students of EU public policy making have explored the interaction between judicial proceedings and policy making. Some are interested in the effect of litigation on policy making, others on litigation during implementation as a later stage in the policy cycle.

There is an important body of research on judicial policy making and, more generally, on the increasingly prominent role of courts in policy making and governance (Stone Sweet 1999; Hirschl 2008). In the EU, we know that the Court has played a crucial role in the construction of the EU legal order (Burley and Mattli 1993; Stone Sweet and Brunell 1998 ) and in favour of market integration and harmonization (Alter and Meunier-Aitsahalia 1994; Scharpf 2010). More recent work has emphasized the influence of rulings in other areas such as social policy (Conant 2006; Martinsen and Falkner 2011), gender equality, environmental issues (Cichowski 2007), health care policy (Martinsen 2015), and gambling policy (Adam 2015). Thus, litigation matters politically because it shapes public policy.

Frequently, these studies explore interactions between the Court, the legislative process, and other relevant stakeholders in detail, even if the overall impact of rulings on policy making is constrained (Martinsen 2015; Mathieu et al. 2018). Yet while a great share of this literature is interested in understanding court agency and the power of the CJEU to influence the course of integration, the full scope of the Court's agency and power relative to other actors and forces in EU policy making is yet to be determined. Among other things, this is due to the prevalence of different theoretical perspectives on the Court and the methodological difficulty inherent in researching court agency when decisions are taken behind closed doors (Vauchez 2015). 
In contrast to these studies, this book focuses mainly on motivations and structural conditions that lead to litigation. In this context, we distinguish political and legal opportunity structures that influence actors' decisions to turn conflict into litigation. In his seminal study on anti-nuclear protest movements, Herbert Kitschelt showed that differences in the openness of national political systems for input and differences in their capacity to implement policies shape the level of protest (Kitschelt 1986; see also Epp 1998; Boyle 1998). Where more access points exist in a political system, for example through separation of powers between the executive and the legislature or centralization of the state, there are fewer structural opportunities for protest and litigation.

While political opportunities certainly play a role in the use of litigation, the literature on social movements' legal mobilization shows that legal opportunities are decisive. Some even argue that legal opportunity structures explain more of the across-country variation in litigation than the respective political opportunity structures (Hilson 2017). Legal opportunity structures comprise two elements: access to courts and legal stock (Hilson 2002; Vanhala 2011). From a procedural perspective, access is enabled or constrained by laws on locus standi or standing rights of the claimant to file suits, court control of their docket, or length of procedures (Vanhala 2012), as well as by rules about who carries the costs of legal procedures. In addition, what matters from a substantive perspective is available precedent case law and the relevant statutory basis to which the conflict can be linked. This legal stock helps lawyers formulate and carry through with legal disputes (Andersen 2005). Social movements obviously have alternative instruments at their disposal to push forward their policy goals. They can rely on lobbying, public protest, or litigation (Bouwen and McCown 2007). The literature found that the extent to which they rely on litigation is highly dependent on the relative openness of the legal system in which they are operating. Where access to courts and judicial review is restrained, social movements tend to turn away from litigation and favour other strategies. By contrast, in countries with a largely unrestricted access to courts, social movements are much more active within the judicial arena (De Fazio 2012).

Turning to EU studies, Alter and Vargas explain variation in the use of litigation strategies to push for equal pay with a combination of political and legal opportunity structures (Alter and Vargas 2000). Conant et al. (2017) state that the increasing relevance of formal law and lawyers who interact with cultural and legal institutions go hand in hand with rises 
in litigation activity. Besides legal and political opportunity structures they deem micro-level characteristics, such as information or available resources in the form of in-house lawyers or pro bono legal advice as well as identity politics, to be important. Hartlapp (2018) has shown that differences in the level of litigation between the Council, the EP, and the Commission can be explained by their different organizational characteristics. According to her, organizational structures inside and across EU institutions must be taken into account when trying to understand legal mobilization in horizontal annulment actions. In the legislative process, the Council can assure its positions most easily. The Commission as agenda setter, in contrast, faces the strongest incentives to mobilize. The EP does so as well to an increasing extent, particularly since the Treaty of Maastricht entered into force. According to Hartlapp (2018), the internal decision-making process provides the Commission with the greatest freedom to launch annulment actions, the Parliament is somewhat constrained by a possible negative vote in the plenary, while the Council needs proactive agreement from all member states to launch an annulment. However, her analysis also indicates that agency inside these institutions matters a great deal.

More generally, mobilization studies have addressed the link between the rise and the impact of litigation. While litigation has initially raised much enthusiasm among social movements, researchers found that judicial success was generally unable to bring about the social changes pursued (Scheingold 1974; Handler 1978, 24; Rosenberg 1991). Nevertheless, social movements were able to draw indirect benefits from litigation, such as raising their own legal capacity and the public awareness of their cause. Litigation was able to consolidate movements' struggling culture and collective identity and thereby triggered mobilization and support to improve their bargaining position in the political arena and change predominant legal understandings and paradigms (Scheingold 1974; Lobel 1994; McCann 1994, 1998, 2008). All of this echoes the argument by Adam et al. (2015) that member states use annulment actions without always aiming at judicial success, as judicial success can be unrelated or even negatively related to the litigant's goal of raising an annulment action in the first place (see also the examples presented in Chapter 1).

Besides its relevance for policy making, litigation also matters at later stages in the policy cycle. We discern three ways in which judicial proceedings matter for implementation and compliance research. Research 
has repeatedly shown that subnational actors play a decisive role during policy implementation. The national failure to comply with $\mathrm{EU}$ law and the subsequent initiation of the infringement procedure by the Commission are often related to conflicts taking place within the member states. For example, the dispersion of powers within the member states (visible as veto players interfering in the implementation of EU policies), can favour implementation failures (Haas 1998; Haverland 2000; Mbaye 2001; Guiliani 2003). Likewise, compliance conflicts with the Commission relate to national party politics (Treib 2003, 2010) and interest-representation systems (Lampinen and Uusikylä 1998; Mbaye 2001). Where such conflicts lead to late or incorrect implementation, subnational actors, in particular private actors, may litigate before national courts to bring their state into compliance with EU law (Börzel 2000; Van der Vleuten 2005; Hartlapp 2008; Hofmann 2016).

Following the top-down perspective of the first generation of American policy implementation scholars (e.g. Pressman and Wildavsky 1973; Dunsire 1978; Sabatier and Mazmanian 1979), EU implementation studies often have an inherent pro-compliance bias. Litigation is either an indicator of an instance in which the Commission has been able to uncover implementation failure (i.e. litigation emerges when member states fail to comply with EU law) or even as an indicator showing how implementation outcomes improved over time. When analysing the role of judicial proceedings in the policy process, implementation scholars want to uncover the conditions of implementation failure. They analyse the conditions under which legal proceedings are used in the EU's system of multilevel governance to bring domestic policies in line with existing European requirements (Mbaye 2001; Hartlapp 2005; Börzel et al. 2010; Steunenberg and Rhinard 2010; Börzel et al. 2012).

From this classical top-down implementation perspective, litigation can be interesting whenever it helps us to capture implementation outcomes and to understand compliance failure. This perspective overlooks, however, that litigation can be chosen as a strategic option by the Commission to advance their goals in the EU policy process (Schmidt 2000; Blauberger and Weiss 2013). By threatening to trigger CJEUdriven policy making in areas where the Council resisted legislation proposed by the Commission, the Commission has managed to change the Council's default position, coaxing member states into action. Related scholarship analyses how policy actors can strategically use the shadow of litigation in order to influence the policy process (Falkner 2011). 
Here, litigation or the threat of litigation matters because it affects the Council's calculations of the cost benefits of adopting new legislation and, as a consequence, affects the balance of power between the Commission and the Council.

Finally, litigation can be looked at as a component of the struggles taking place between implementing actors, along the lines of the bottom-up approach of the American policy implementation literature (Lipsky 1971, 1980; Elmore 1979; Barret and Fudge 1981). Here, turning the implementation perspective on its head, implementation is conceptualized to depend primarily on the multiple actors at the application level. From this perspective, conflict and struggle is not an anomaly but rather a natural component of the policy process. Consequently, litigation is best understood as part of these struggles about the outcome of EU public policy making. ${ }^{1}$

In sum, the literature on implementation, compliance, and Europeanization has so far underlined three ways in which judicial proceedings interact with the EU public policy process. First, scholars interested in compliance have shown that proceedings can help improve national compliance with EU legislation. Second, we also know that the shadow of litigation can be used by the Commission to increase its power vis-à-vis the Council in the EU policy-making process. Third, it has shown that domestic politics often determines the way in which member states react to the CJEU's rulings. With these analytical focal points, this literature has predominantly focused on the impact of the judicial proceedings (or the threat thereof) on multilevel policy dynamics. However, what about the inverse relationship? How do multilevel politics affect the emergence of litigation?

If we combine the insights concerning litigation from the multilevel governance literature and from the implementation and Europeanization literature, it should be clear that litigation and jurisprudence do not emerge in a political vacuum. Neither does annulment litigation. On the one hand, we need to study the impact of annulment rulings by analysing how they feed back into conflictive multilevel policy processes. Who are the winners and losers of annulment actions? Are actors losing the legal battle also always losing the underlying political battle? On the other hand, we need to assess how annulment litigation emerges from (supranational) compliance failures as well as from more general dysfunctionalities and conflicts in the multilevel governance process. What can different kinds of litigant configurations tell us about the underlying political conflicts in this regard? 


\section{Judicial Politics and Judicial Success}

Finally, the literature on judicial politics and judicial behaviour provides obvious insights that need to be taken into account in any kind of analysis of annulment litigation. In the EU context, the question of judicial behaviour relates to how judges of the CJEU make their decisions. Legalists emphasize judicial objectivity, claiming that judges' decisions are predetermined by EU law (Barav 1979). They reject the idea that judges' decisions are influenced by political or ideological preferences. Judges' work is conceived as purely technical, apolitical, and based on methodologies of legal interpretation. Yet several alternative models of judicial behavioural models, strongly informed and influenced by judicial politics in the United States, have been developed. Proponents of an attitudinal model of judicial decision making claim that judgements and legal interpretations are never fully determined by the objective merits of a case or by a specific legal method (Segal and Spaeth 2002, $53)$. Rather, there is a margin of interpretation of the law and of the case. This gives judges a lot of freedom within these margins and grey areas, which they can use to rule in accordance with their ideological preferences. In the case of the CJEU, judges are said to be ideologically biased in favour of European integration (Mattli and Slaughter 1998). Moreover, there are proponents of a strategic approach to judicial behaviour. This approach acknowledges judges' discretion and the need for interpretation, too. Yet proponents of the strategic approach contend that judges cannot freely use their freedom for interpretation to impose their ideologically preferred outcomes. Since they rely on the acceptance of their judgements and wish to uphold their authority as a well-accepted institution, they have to take the expectations of key litigants and societal stakeholders into account as well. In this sense, they will adjust their judgements to the specifics of the respective (political or social) situation and rule in a way that will avoid widespread disagreement and political retaliation (Segal and Spaeth 2002, 100). In the context of the CJEU, for example, judges' capacity to follow their preference for EU integration is argued to be limited by the anticipated reactions to their rulings by key member states (Garrett et al. 1998; Carrubba et al. 2008; Larsson and Naurin 2016; Dederke and Naurin 2018 ). The presumed need to rule strategically in order to avoid noncompliance or political retaliation constrains the Court's formal independence. Carrubba et al. (2008) show, for example, that when a large 
number of powerful member states oppose the Commission in court, the Commission's chances for success are substantially lower than when it does not face such an opposition. According to Carrubba and his colleagues, this effect is due to the Court's anticipation of the member states' reactions to its rulings. When several strong member states take part in a judicial conflict, the Court may anticipate that a ruling that would be negative for them could be neutralized through legislative override. Besides, member states enjoying the status of strong political power in Brussels are less vulnerable to reputation pressures and, therefore, are more likely (than weak member states) not to comply with a ruling that is problematic for them.

Interestingly, the scholarly debate about whether or not the CJEU is in fact contained by member state influence (Conant 2002) is-by and large - a debate about whether the Court is independent or not. Consequently, this debate risks losing track of the possibility that the Court might be very independent in some context but rather constrained in other contexts. According to Mathieu et al. (2018), it is, however, essential to keep this possibility in mind and to explore to what extent the policy context from which litigation emerges systematically mediates the Court's behaviour. This policy context might lead the Court to be more concerned with strategic concerns, giving it more room for ideologically biased interpretations, or it might confront the Court with very different kinds of legal questions. Since extant research has mainly looked at CJEU behaviour in the context of preliminary reference procedures, it has mainly looked at the involvement of member state governments submitting legal briefs to the Court. Whenever we deal with actions for annulment, however, we are likely to encounter a more diverse and complex actor constellation, which can include member state governments, regional governments, interest groups, companies, and EU institutions all at the same time. In light of extant research on judicial behaviour, this empirical fact highlights the need to analyse the conditions that give rise to such complex actor configurations. Moreover, it feeds the interest in whether these litigant configurations influence the Court in any kind of way. In any case, an exploration of the role and impact of annulment litigation cannot ignore judicial behaviour and the potential relationship between potentially quite complex actor configurations and judicial behaviour. 


\section{Conceptualizing Multilevel Annulment Conflict}

Actor configurations in multilevel policy conflicts and in annulment actions are key analytical interests to us. Essentially, we distinguish between horizontal and vertical annulment conflicts depending on the location of the main opponents in the multilevel system. Moreover, we distinguish between simple and complex actor configurations.

\section{Horizontal v. Vertical Conflict}

In cases in which supranational institutions litigate against another supranational institution, the cleavage is horizontal. The conflict runs between actors situated at the same level of the EU system. Take the EP as an example. Traditionally, the EP held powers to decide about non-compulsory budget spending and has used these competences to strategically expand its powers, for example by increasing non-compulsory expenditures. When the Council challenges the legality of the general budget (e.g. C-34/86), it carries conflict between the two EU institutions to the judicial arena. Such conflict may emerge between other institutions situated at the supranational level of the EU system, too. We refer to these cases as horizontal cases, since both opponents are located at the supranational level (see Fig. 2.1).

In contrast, in actions initiated by actors from the national levelwhether these are national governments, regional entities, or private actors-the dominant conflict cleavage is vertical. Therefore, we refer to these cases as vertical conflicts throughout the book (see Fig. 2.2). Good examples for this are conflicts over the appropriation of EU funds when these supranational funds are spent and administered by national entities. Where EU institutions try to interfere in a legally binding way with how to spend and administer that money or decide that national entities

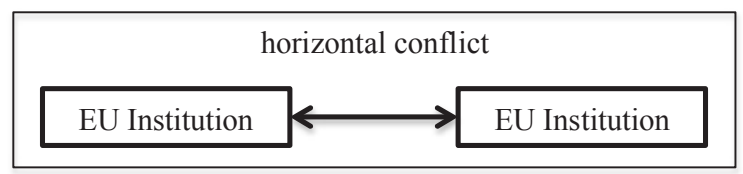

Fig. 2.1 Horizontal conflicts (Source Own compilation) 
Fig. 2.2 Vertical conflicts (Source Own compilation)

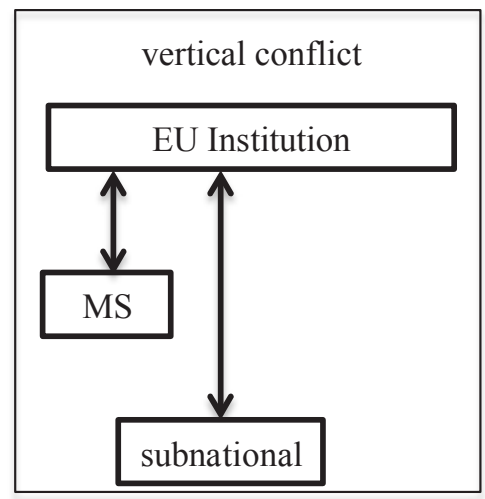

have misspent that money, we often witness vertical conflict that regularly leads to annulment litigation with vertical actor configurations (as depicted in Fig. 2.2).

Based on the location of the applicant for legal action within the multilevel system, we thus distinguish between different kinds of annulment conflicts. Since the legal defendant in these situations is always situated at the EU level, this distinction is mainly driven by the location of the applicant at either the national level (vertical conflicts), or the supranational level (horizontal conflicts).

\section{Simple v. Complex Conflicts}

Moreover, we consider conflicts to have complex actor configurations where they involve more than one actor on either side of the judicial conflict. Whereas the primary conflict cleavage determines whether conflicts are considered as vertical or horizontal conflicts, the annulment conflicts are often characterized by additional secondary conflict cleavages. Member state governments or other EU institutions can join horizontal conflicts by acting either as additional litigant or as intervener in support of the supranational litigant. Thereby, these horizontal conflicts acquire an additional vertical conflict cleavage. In these cases, the member state and the supranational institution form a multi-actor, and in fact multilevel, alliance against the defending EU institution. Importantly, however, this vertical cleavage can exist on either side of the conflict. 
Member state governments can act in ways other than in support of applicant institutions. They can also oppose them by joining the case in support of the defendant. In these cases, the litigant institution faces a multi-actor defence coalition. We can even find configurations characterized by a situation in which multi-actor applicant coalitions confront multi-actor defence coalitions (see Fig. 2.3). All of these multilevel horizontal conflicts are complex conflicts. Such a conflict configuration emerged, for example, over the regulation of the hazardous substance decabromodiphenyl ether (DecaBDE) in which the EP and Denmark, with the support of Finland and Sweden, initiated, actions for annulment against the Commission, which was itself supported by the United Kingdom (C-14/06).

Yet complexity is not always induced by the involvement of member state governments joining horizontal conflicts. Additional EU institutions that join cases on the side of the applicant institution or on the side of the defendant institution can also induce complexity. A good example of this is the negotiation of an agreement between the EU and the United States of America on the processing and transfer of passenger

horizontal conflict with complex actor constellations
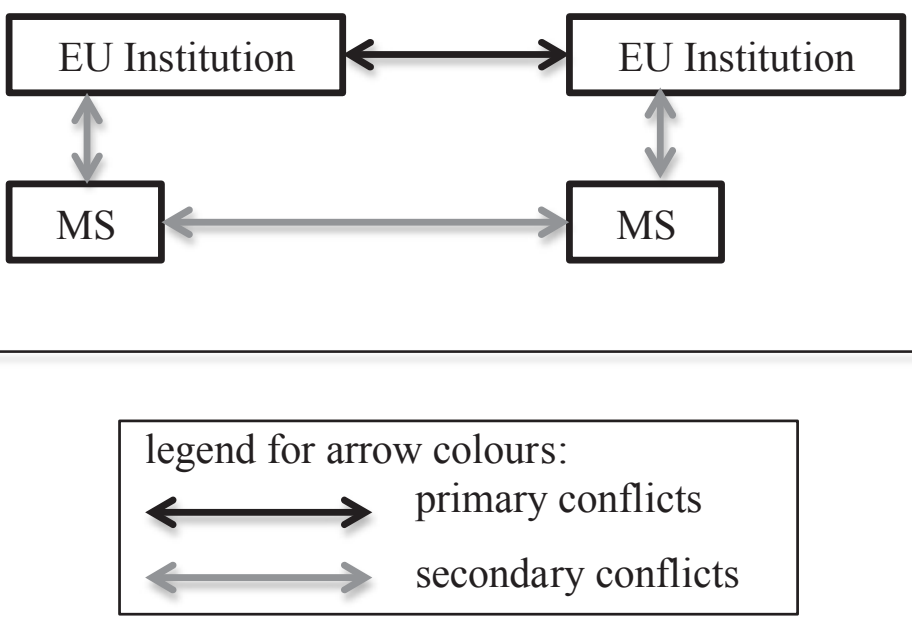

Fig. 2.3 Complex horizontal conflicts (Source Own compilation) 
name record data. The Council had proposed that air carriers should be allowed to transfer the data to the United States Department of Homeland Security, while the EP-being concerned with citizens' data privacy-questioned this practice. Sharing these concerns, the European Data Protection Supervisor sided with Parliament once an action for annulment was initiated (joined cases C-317/04 and C-318/04). On the defendant side, the Council found support from the European Commission and the United Kingdom, all of whom defended the agreement in court (Hillion and Wessel 2009, 576). Whenever such secondary cleavages are relevant, we consider conflicts to be complex actor configurations as opposed to simple actor configurations. ${ }^{2}$

Similarly, vertical cases can also be characterized by more than one conflict, with additional and important secondary conflict lines. Other member state governments might object to the application for annulment and join to support the defending EU institution. The same is true for other subnational actors. This way, the conflict between two member state governments can find expression in them supporting different sides in the conflict as illustrated schematically (see Fig. 2.4).

\section{A Multilevel and Multi-step Analytical Approach}

This conceptual approach guides and structures the remainder of this book. While we address each research question individually, our analytical goal is to formulate a more general argument about how elements of the public policy process and elements of the judicial process feed into each other to determine the political role of actions for annulment. While the policy context of the cases may explain actors' decision to take use annulments, these decisions influence-but do not determineeventual litigant configurations. In turn, the litigant configuration representing the structure of the legal conflict is able to affect the legal discourse during proceedings. After all, litigants take part in proceedings because they hope to influence these in their favour. The information and arguments made by the different kinds of litigants can influencebut hardly determines-the Court's interpretations and judgement. These interpretations and judgements not only determine legal winners and losers, but also affect the policy substance and the distribution of competences in the EU's system of multilevel governance by influencing current and future policy context from which new conflicts arise. 


\section{vertical conflict with complex actor constellations}
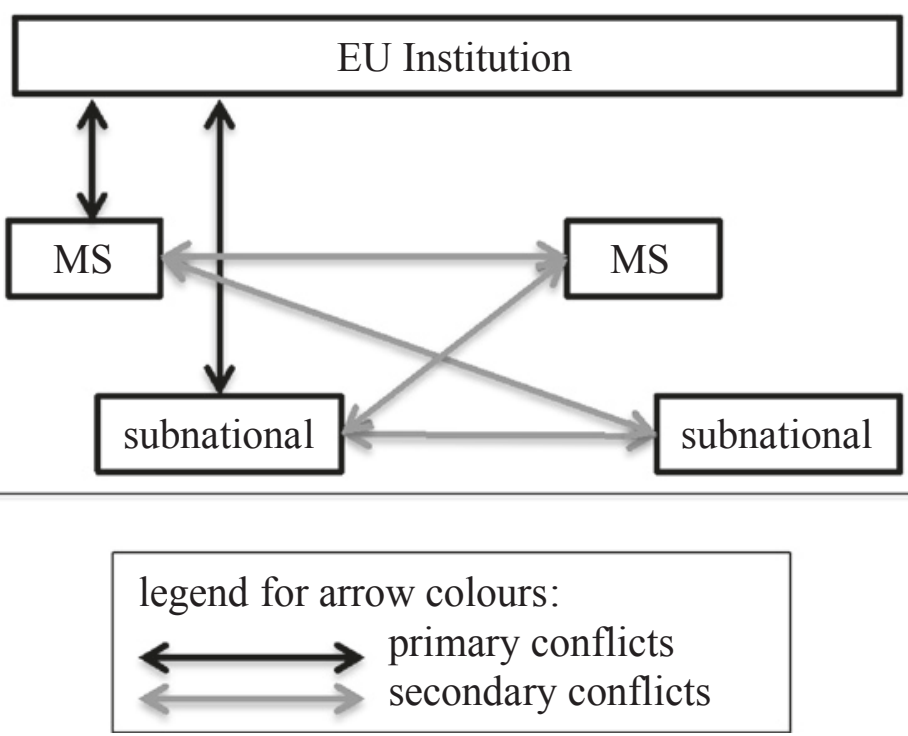

Fig. 2.4 Complex vertical conflicts (Source Own compilation)

The process that in the end determines the impact of court rulings thus resembles an analytical chain that has been studied already. Referring to a filtering process, delta, or funnel, these works look at the chain of events as a narrowing passageway and seek to understand what shapes the eventual litigation (Klages 1983; Glenn 1999; Van Waarden and Hildebrand 2009). In contrast, the principal contribution of this book consists of promoting a comprehensive approach to studying the role of judicial proceedings by analysing them within multiple interrelated steps as one element within a continuous multilevel policy process. Thereby, we try to go beyond looking merely at the use of litigation, at litigant configurations, or at judges' decisions in isolation. Instead, we consider them to be linked in a chain-like fashion. A comprehensive understanding of annulment litigation in the multilevel system must take this chain-like linkage into account. This view has affinities with the policy-cycle perspective (Easton 1965), composed of distinct phases that 
feed into each other (agenda setting, policy making, policy implementation, evaluation, agenda setting). Likewise, the way judicial proceedings intervene in the multilevel policy process can be looked at as a sequential chain, where multilevel policy conflicts lead to litigation and structures litigant configuration. This, in turn, affects judicial outcomes, which, through their policy and institutional impacts, feed back into the multilevel policy process. The chain-like approach that centres on litigants as the starting point to policy change is thus very similar to the bottom-up approach within the implementation literature.

Based on this analytical and conceptual foundation, the next chapter will provide the relevant information about the legal background of annulment actions (Chapter 3 ). We will then briefly explain our methodological approach (Chapter 4) before presenting three empirical chapters addressing the questions mentioned above. First, we will explore the motivations underlying policy actors' use of annulment actions (Chapter 5). Second, we will address the rise of complex actor constellations in annulments proceedings (Chapter 6). We will finalize our empirical investigation with judicial success and the impact of annulment actions (Chapter 7) before we draw general conclusions in a final chapter (Chapter 8).

\section{Cases Cited}

See Table 2.1.

Table 2.1 Cases cited in this chapter

\begin{tabular}{ll}
\hline C-34/86 & Judgment of 3 July 1986, Council v. Parliament, C-34/86, \\
& EU:C:1986:291 \\
C-317/04; C-318/04 & Judgment of 30 May 2006, Parliament v. Council, Joined \\
& Cases C-317/04 and C-318/04, EU:C:2006:346 \\
C-14/06 & Judgment of 1 April 2008, Parliament v. Commission, \\
& C-14/06, EU:C:2008:176
\end{tabular}

\section{Notes}

1. Following this line of reasoning, some authors integrated court rulings and the CJEU into Europeanization research emphasizing the way national struggles co-shape the policy implementation process. These works discuss conflict structures in the national arena as an explanation for national 
response to the CJEU's case law (Blauberger 2012, 2014; Schmidt 2012, 2014).

2. In a recent article on Norwegian Supreme Court judgements, Skiple et al. (2016) use a similar but wider definition of complex cases identified 'through the number of third parties supporting a litigant (i.e. legal intervenient), the number of justices who voice their opinion and the number of words in the majority opinion' (Skiple et al. 2016, 9).

\section{REFERENCES}

Adam, C. (2015). Gambling: Erosion and persistence of domestic sports betting monopolies. In C. Knill, C. Adam, \& S. Hurka (Eds.), On the road to permissiveness? Change and convergence of moral regulation in Europe (pp. 206-233). Oxford, UK: Oxford University Press.

Adam, C., Bauer, M. W., \& Hartlapp, M. (2015). It's not always about winning: Domestic politics and legal success in EU annulment litigation. Journal of Common Market Studies, 53(2), 185-200.

Alter, K. J., \& Meunier-Aitsahalia, S. (1994). Judicial politics in the European Community: European integration and the pathbreaking Cassis de Dijon decision. Comparative Political Studies, 26(4), 535-561.

Alter, K. J., \& Vargas, J. (2000). Explaining variation in the use of European litigation strategies: European Community law and British gender equality policy. Comparative Political Studies, 33(4), 452-482.

Andersen, E. A. (2005). Out of the closets and into the courts legal opportunity structure and gay rights litigation. Ann Arbor: The University of Michigan Press.

Barav, A. (1979). The judicial power of the European Economic Community Symposium: Conference on comparative constitutional law. Southern California Law Review 53, 461-526.

Barrett, S., \& Fudge, C. (Eds.). (1981). Policy and action. London: Methuen.

Bauer, M. W. (1996). Die Verbindungsbüros der Deutschen Länder bei der Europäischen Union in Brüssel. Verwaltungsrundschau, 42(12), $417-420$.

Bauer, M. W. (2001). A creeping transformation? The European Commission and the management of EU structural funds in Germany. Dordrecht, The Netherlands: Kluwer Academic (Library of Public Policy and Public Administration).

Bauer, M. W. (2002). The EU 'partnership principle': Still a sustainable governance device across multiple administrative arenas? Public Administration, $80(4), 769-789$. 
Bauer, M. W., \& Becker, S. (2014). The unexpected winner of the crisis: The European Commissions strengthened role in economic governance. Journal of European Integration, 36(3), 213-229.

Bauer, M. W., \& Trondal, J. (Eds.). (2015a). The Palgrave handbook of the European administrative system. Basingstoke: Palgrave Macmillan.

Bauer, M. W., \& Trondal, J. (2015b). The administrative system of the European Union. In M. W. Bauer \& J. Trondal (Eds.), The Palgrave handbook of the European administrative system (pp. 1-28). Basingstoke: Palgrave Macmillan.

Benz, A., \& Eberlein, B. (1999). The Europeanization of regional policies: Patterns of multi-level governance. Journal of European Public Policy, 6(2), 329-348.

Biesenbender, J. (2011). The dynamics of treaty change: Measuring the distribution of power in the European Union. European Integration Online Papers (EIoP), 15(5), 1-24.

Blau, P. M. (1977). Inequality and heterogeneity: A primitive theory of social structure. London: Macmillan.

Blauberger, M. (2012). With Luxembourg in mind ... the remaking of national policies in the face of ECJ jurisprudence. Journal of European Public Policy, $19(1), 109-126$.

Blauberger, M. (2014). National responses to European court jurisprudence: West European politics. West European Politics, 37(3), 457-474. https://doi. org/10.1080/01402382.2013.830464.

Blauberger, M., \& Weiss, M. (2013). If you can't beat me, join me! How the Commission pushed and pulled member states into legislating defence procurement. Journal of European Public Policy, 20(8), 1120-1138.

Börzel, T. A. (2000). Why there is no southern problem: On environmental leaders and laggards in the European Union. Journal of European Public Policy, 7, 141-162.

Börzel, T. A. (2005). Mind the gap! European integration between level and scope. Journal of European Public Policy, 12(2), 217-236.

Börzel, T. A., Hofman, T., \& Panke, D. (2012). Caving in or sitting it out? Longitudinal patterns of non-compliance in the European Union. Journal of European Public Policy, 19(4), 454-471.

Börzel, T. A., Hofmann, T., Panke, D., \& Sprungk, C. (2010). Obstinate and inefficient: Why member states do not comply with European law. Comparative Political Studies, 43(11), 1363-1390. https://doi.org/10.1177/ 0010414010376910.

Bouwen, P., \& Mccown, M. (2007). Lobbying versus litigation: Political and legal strategies of interest representation in the European Union. Journal of European Public Policy, 14(3), 422-443.

Boyle, E. H. (1998). Political frames and legal activity: The case of nuclear power in four countries. Law and Society Review, 32(1), 141-174. 
Burley, A.-M., \& Mattli, W. (1993). Europe before the court: A political theory of legal integration. International Organization, 47(1), 41-76.

Carrubba, C. J., Gabel, M., \& Hankla, C. (2008). Judicial behavior under political constraints: Evidence from the European Court of Justice. American Political Science Review, 102(4), 435-452.

Christiansen, T., \& Kirchner, E. J. (2000). Committee governance in the European Union. Manchester, UK: Manchester University Press.

Christiansen, T., \& Neuhold, C. (2013). Informal politics in the EU. Journal of Common Market Studies, 51(6), 1196-1206.

Cichowski, R. A. (2007). The European court and civil society. Cambridge, UK: Cambridge University Press.

Conant, L. J. (2002). Justice contained: Law and politics in the European Union. Ithaca, NY: Cornell University Press.

Conant, L. J. (2006). Individuals, courts, and the development of European social rights. Comparative Political Studies, 39(1), 76-100.

Conant, L., Hofmann, A., Soennecken, D., \& Vanhala, L. (2017). Mobilizing European law. Journal of European Public Policy, 25(9), 1-14. https://doi. org/10.1080/13501763.2017.1329846.

Corbett, R., Jacobs, F., \& Shackleton, M. (2011). The European Parliament. London: John Harper.

Crespy, A., \& Saurugger, S. (2014). Resistance to policy change in the European Union: An actor-centered perspective. Cabiers Du Cevipol, 2014(1), 1-20.

Dederke, J., \& Naurin, D. (2018). Friends of the Court? Why EU governments file observations before the Court of Justice. European Journal of Political Research, 57(4), 867-882. https://doi.org/10.1111/1475-6765.12255.

De Fazio, G. (2012). Legal opportunity structure and social movement strategy in Northern Ireland and Southern United States. International Journal of Comparative Sociology, 53(1), 3-22. https://doi.org/10.1177/ 0020715212439311.

Dehousse, R. (1997). Regulation by networks in the European Community: The role of European agencies. Journal of European Public Policy, 4(2), 246-261.

Dunsire, A. (1978). The execution process: Implementation in a bureaucracy. Los Gatos, CA: Martin Robertson.

Easton, D. (1965). A framework for political analysis. Englewood Cliffs, NJ: Prentice Hall/Harvester Wheatsheaf.

Ege, J., Bauer, M. W., \& Becker, S. (2018). The European Commission in turbulent times: Assessing organizational change and policy impact. Baden-Baden, Germany: Nomos.

Egeberg, M. (2006). Multilevel Union administration: The transformation of executive politics in Europe. New York: Palgrave Macmillan.

Elmore, R. F. (1979). Backward mapping: Implementation research and policy decisions. Political Science Quarterly, 94(4), 601-616. 
Epp, C. R. (1998). The rights revolution: Lawyers, activists, and supreme courts in comparative perspective. Chicago: University of Chicago Press.

Falkner, G. (Ed.). (2011). The EU's decision traps: Comparing policies. Oxford, UK: Oxford University Press.

Farrell, H., \& Héritier, A. (2007). Contested competences in the European Union. West European Politics, 30(2), 227-243.

Garrett, G., Kelemen, R. D., \& Schulz, H. (1998). The European Court of Justice, national governments, and legal integration in the European Union. International Organization, 52(1), 149-176.

Glenn, H. (1999). Paths to justice: What people do and think about going to law. Oxford, UK: Hart Publishing.

Glöckler, G., Lindner, J., \& Salines, M. (2016). Explaining the sudden creation of a banking supervisor for the euro area. Journal of European Public Policy, 24(8), 1135-1153. https://doi.org/10.1080/13501763.2016.1184296.

Guiliani, M. (2003). Europeanization in comparative perspective: Institutional fit and national adaptation. In K. Featherstone \& C. M. Radaelli (Eds.), The politics of Europeanization (pp. 134-155). Oxford, UK: Oxford University Press.

Haas, P. M. (1998). Compliance with EU directives: Insights from international relations and comparative politics. Journal of European Public Policy, 5(1), 17-37.

Handler, J. F. (1978). Social movements and the legal system: A theory of law reform and social change. Cambridge, MA: Academic Press.

Hartlapp, M. (2005). Die Kontrolle der nationalen Rechtsdurchsetzung durch die Europäische Kommission. Frankfurt: Campus Verlag.

Hartlapp, M. (2008). Extended governance: Implementation of EU social policy in the member states. In I. Tömmel \& A. Verdun (Eds.), Innovative governance in the European Union: The politics of multilevel policymaking (pp. 221-236). Boulder, CO: Lynne Rienner.

Hartlapp, M. (2018). Power shifts via the judicial arena: How annulments cases between EU institutions shape competence allocation. Journal of Common Market Studies, 56(6), 1429-1445.

Haverland, M. (2000). National adaptation to European integration: The importance of institutional veto points. Journal of Public Policy, 20(1), 83-103.

Hillion, C., \& Wessel, R. A. (2009). Competence distribution in EU external relations after ECOWAS: Clarification or continued fuzziness? Common Market Law Review, 46(2), 551-586.

Hilson, C. (2002). New social movements: The role of legal opportunity. Journal of European Public Policy, 9(2), 238-255.

Hilson, C. (2017). Protest and litigation against nuclear power in the 1970s: Exploring political and legal opportunity structure. Paper presented at CES Glasgow 2017. 
Hirschl, R. (2008). The judicialization of politics. In K. E. Whittington, D. R. Kelemen, \& G. A. Caldeira (Eds.), The Oxford handbook of law and politics (pp. 1-23). Oxford, UK: Oxford University Press. https://dx.doi. org/10.1093/oxfordhb/9780199604456.013.0013.

Hix, S. (2011). The political system of the European Union (3rd ed.). Basingstoke, UK: Palgrave Macmillan.

Hofmann, A. (2016). Legal rights and practical effect: Why the European Commission supports access to justice for interest groups. Conference Paper: Workshop implementation and judicial politics: Conflict and compliance in the EU multi-level system.

Holzinger, K., \& Schimmelfennig, F. (2012). Differentiated integration in the European Union: Many concepts, sparse theory, few data. Journal of European Public Policy, 19(2), 292-305.

Hooghe, L. (1996). Cohesion policy and European integration: Building multilevel governance. Oxford, UK: Oxford University Press.

Hooghe, L., \& Marks, G. (2001). Multi-level governance and European integration. Lanham, MD: Rowman \& Littlefield.

Hooghe, L., \& Marks, G. (2009). A postfunctionalist theory of European integration: From permissive consensus to constraining. British Journal of Political Science, 39(1), 1-23.

Horowitz, D. L. (1985). Ethnic groups in conflict. Berkeley: University of California Press.

Kelemen, R. D. (2011). Eurolegalism. Cambridge, MA: Harvard University Press.

Klages, H. (1983). Ursachenfaktoren der Inanspruchnahme der Ziviljustiz. Deutsche Richterzeitung, 10, 395-436.

Kitschelt, H. P. (1986). Political opportunity structures and political protest: Anti-nuclear movements in four democracies. British Journal of Political Science, 16(1), 57-85.

Kvist, J. (2004). Does EU enlargement start a race to the bottom? Strategic interaction among EU member states in social policy. Journal of European Social Policy, 14(3), 301-318.

Lampinen, R., \& Uusikylä, P. (1998). Implementation deficit-Why member states do not comply with EU directives? Scandinavian Political Studies, $21(3), 231-251$.

Larsson, O., \& Naurin, D. (2016). Judicial independence and political uncertainty: Assessing the effect of legislative override on the European Court of Justice. International Organization, 70(2), 377-408.

Lipsky, M. (1971). Street-level bureaucracy and the analysis of urban reform. Urban Affairs Quarterly, 6, 391-409.

Lipsky, M. (1980). Street-level bureaucracy. New York: Sage.

Lobel, J. (1994). Losers fools and prophets: Justice as struggle. Cornell Law Review, 80, 1331-1421. 
Marks, G. (1993). Structural policy and multilevel governance in the EC. In A. Cafruny \& G. Rosenthal (Eds.), The state of the European Community: The Maastricht debates and beyond (Vol. 2, pp. 391-410). Harlow, UK: Longman.

Marks, G., Scharpf, F. W., Schmitter, P. C., \& Streek, W. (Eds.). (1996). Governance in the European Union. Thousand Oaks, CA: Sage.

Martinsen, D. S. (2015). An ever more powerful court? The political constraints of legal integration in the European Union. Oxford, UK: Oxford University Press.

Martinsen, D. S., \& Falkner, G. (2011). Social policy: Problem solving gaps, partial exits and court-decision traps. In G. Falkner (Ed.), The EUs decision traps: Comparing policies (pp. 128-145). Oxford, UK: Oxford University Press.

Mathieu, E., Adam, C., \& Hartlapp, M. (2018). From high judges to policy stakeholders: A public policy approach to the CJEUs power. Journal of European Integration, 40(6), 653-666.

Mathieu, E., \& Bauer, W. M. (2018). Domestic resistance against EU policy implementation: Member states motives to take the Commission to court. Journal of European Integration, 40(6), 667-682.

Mattli, W., \& Slaughter, A.-M. (1998). Revisiting the European Court of Justice. International Organization, 52(1), 177-209. https://doi.org/10.1162/ 002081898550590.

Mazey, S., \& Richardson, J. J. (1993). Lobbying in the European Community. Oxford, UK: Oxford University Press.

Mbaye, H. A. D. (2001). Why national states comply with supranational law: Explaining implementation infringements in the European Union 19721993. European Union Politics, 2(3), 259-281.

McCann, M. W. (1994). Rights at work: Pay equity reform and the politics of legal mobilization. Chicago: University of Chicago Press.

McCann, M. W. (1998). How does law matter for social movements? In B. G. Garth \& A. Sarat (Eds.), How does law matter? Evanston, IL: Northwestern University Press.

McCann, M. W. (2008). Litigation and legal mobilization. In K. E. Whittington, D. R. Kelemen, \& G. A. Caldeira (Eds.), The Oxford handbook of law and politics (pp. 1-25). Oxford, UK: Oxford University Press. https://dx.doi. org/10.1093/oxfordhb/9780199208425.003.0030.

McLaughlin, A., \& Greenwood, J. (1995). The management of interest representation in the European Union. Journal of Common Market Studies, 33, $143-156$.

Meardi, G. (2000). Trojan horse for the Americanization of Europe? Polish industrial relations towards the EU. European Journal of Industrial Relations, $8(1), 77-99$.

Naurin, D., \& Wallace, H. (Eds.). (2008). Unveiling the Council of the European Union: Games governments play in Brussels. Basingstoke: Palgrave Macmillan. 
Pluemper, T., \& Schneider, C. J. (2007). Discriminatory European Union membership and the redistribution of enlargement gains. Journal of Conflict Resolution, 51(4), 568-587.

Pressman, J. L., \& Wildavsky, A. B. (1973). Implementation: How great expectations in Washington are dashed in Oakland-Or, why it's amazing that federal programs work at all, this being a saga of the Economic Development Administration as told by two sympathetic observers who seek to build morals on a foundation of ruined hopes. Berkeley: University of California Press.

Rosenberg, G. N. (1991). The hollow hope: Can courts bring about social change? (lst ed.). Chicago: University of Chicago Press.

Sabatier, P., \& Mazmanian, D. (1979). The conditions of effective implementation: A guide to accomplishing policy objectives. Policy Analysis, 5(4), 481-504.

Saurugger, S., \& Terpan, F. (2013). Analyser les résistances nationales à la mise en œuvre des normes européennes: une étude des instruments daction publique. Quaderni, 80, 5-24.

Scharpf, F. W. (1985). Die Politikverflechtungs-Falle. Europäische Integration und deutscher Föderalismus im Vergleich. Politische Vierteljahresschrift, 26(4), 323-356.

Scharpf, F. W. (2006). The joint-decision trap revisited. Journal of Common Market Studies, 44(4), 845-864.

Scharpf, F. W. (2010). The asymmetry of European integration, or why the EU cannot be a social market economy. Socio-Economic Review, 8(2), $211-250$.

Scharpf, F. W. (2017). Vom asymmetrischen Euro-Regime in die Transferunion - und was die deutsche Politik dagegen tun könnte (MPIfG Discussion Paper 17/15). Cologne, Germany: Max Planck Institute for the Study of Societies.

Scheingold, S. (1974). The politics of rights: Lawyers, public policy, and social change. New Haven, CT: Yale University Press.

Schmidt, S. K. (2000). Only an agenda setter? The European Commissions power over the council of ministers. European Union Politics, 1(1), 37-61.

Schmidt, S. K. (2012). Who cares about nationality? The path-dependent case law of the ECJ from goods to citizens. Journal of European Public Policy, 19(1), 8-24. https://doi.org/10.1080/13501763.2012.632122.

Schmidt, S. K. (2014). Judicial Europeanisation: The case of Zambrano in Ireland. West European Politics, 37(4), 769-785. https://doi.org/10.1080/ 01402382.2014 .919775 .

Segal, J. A., \& Spaeth, H. J. (2002). The Supreme Court and the attitudinal model revisited. Cambridge, UK: Cambridge University Press.

Skiple, J. K., Grendstad, G., Shaffer, W. R., \& Waltenburg, E. N. (2016). Supreme Court justices economic behaviour: A multilevel model analysis. Scandinavian Political Studies, 39(1), 73-94. https://doi.org/10.1111/ 1467-9477.12060. 
Steunenberg, B., \& Rhinard, M. (2010). The transposition of European law in EU member states: Between process and politics. European Political Science Review, 2(3), 495-520.

Stone Sweet, A. (1999). Judicialization and the construction of governance. Comparative Political Studies, 32(2), 147-184.

Stone Sweet, A., \& Brunell, T. L. (1998). Constructing a supranational constitution: Dispute resolution and governance in the European Community. American Political Science Review, 92(1), 63-81.

Swenden, W. (2006). Federalism and regionalism in Western Europe: A comparative and thematic analysis. Basingstoke: Palgrave.

Tatham, M., \& Bauer, M. W. (2014a). Competence ring-fencing from below? The drivers of regional demands for control over upwards dispersion. Journal of European Public Policy, 21(9), 1367-1385.

Tatham, M., \& Bauer, M. W. (2014b). Support from below? Supranational institutions, regional élites, and governance preferences. Journal of Public Policy, 34(2), 237-267.

Tömmel, I., \& Verdun, A. (Eds.). (2008). Innovative governance in the European Union: The politics of multilevel policymaking. Boulder, CO: Lynne Rienner.

Treib, O. (2003). Die Umsetzung von EU-Richtlinien im Zeichen der Parteipolitik: Eine akteurszentrierte Antwort auf die Misfit-These. Politische Vierteljabresschrift, 44(4), 506-528.

Treib, O. (2010). Party politics, national interests, and government-Opposition dynamics cleavage structures in the convention negotiations on EU social policy. European Union Politics, 11(1), 119-142.

Trondal, J., \& Bauer, M. W. (2017). Conceptualizing the European multilevel administrative order: Capturing variation in the European administrative system. European Political Science Review, 9(1), 73-94.

Van Der Vleuten, A. (2005). Pincers and prestige: Explaining the implementation of EU gender equality legislation. Comparative European Politics, 3, $464-488$.

Vanhala, L. (2011). Making rights a reality? Disability rights activists and legal mobilization. Cambridge, UK: Cambridge University Press.

Vanhala, L. (2012). Legal opportunity structures and the paradox of legal mobilization by the environmental movement in the UK. Law and Society Review, $46(3), 523-556$.

Van Waarden, F., \& Hildebrand, Y. (2009). From corporatism to lawyocracy? On liberalization and juridification. Regulation and Governance, 3(3), 259-286. https://doi.org/10.1111/j.1748-5991.2009.01059.x.

Vauchez, A. (2015). Methodological Europeanism at the cradle: Eur-lex, the Acquis and the making of Europe's cognitive equipment. Journal of European Integration, 37(2), 193-210. 
Open Access This chapter is licensed under the terms of the Creative Commons Attribution 4.0 International License (http://creativecommons.org/licenses/ by $/ 4.0 /$ ), which permits use, sharing, adaptation, distribution and reproduction in any medium or format, as long as you give appropriate credit to the original author(s) and the source, provide a link to the Creative Commons license and indicate if changes were made.

The images or other third party material in this chapter are included in the chapter's Creative Commons license, unless indicated otherwise in a credit line to the material. If material is not included in the chapter's Creative Commons license and your intended use is not permitted by statutory regulation or exceeds the permitted use, you will need to obtain permission directly from the copyright holder.

(c) 